\title{
PHYTOCHEMISTRY AND SOME HAEMATOLOGICAL CHANGES FOLLOWING ORAL ADMINISTRATION OF ETHANOLIC ROOT EXTRACT OF GONGLONEMA LATIFOLIUM IN RATS
}

\author{
A. B. ANTAI, O. E. OFEM, D. E. IKPI, S. UKAFIA ${ }^{1}$, AND E. A. AGIANG ${ }^{2}$ \\ Department of Physiology, College of Medical Sciences, University of Calabar-Nigeria. 1Department of \\ Anatomy, Faculty of Health Sciences, University of Uyo, Uyo, Nigeria. 2Department of Animal Sciences, \\ Faculty of Agriculture, University of Calabar, Calabar, Nigeria. E-mail: eduanwana@yahoo.com
}

\begin{abstract}
Summary: Gonglonema latifolium is a climbing perennial plant that belongs to the family of asclepidaceae. The medicinal uses of the leaves and stem bark extract of Gonglonema latifolium has been reported in many scientific literatures to include anti-hyperglycaemic, anti-ulcerative etc. There is paucity in scientific reports on the medicinal properties of the root extract. This study was therefore designed to elucidate the phytochemical constituents and effect of ethanolic root extract of Gonglonema latifolium on some hematological parameters. Eighteen (18) albino Wistar rats were randomly assigned into 3 groups of 6 rats each. Group 1 (control) was fed on normal rat chow + drinking water, the test groups (group 2 and 3) in addition received extract treatment (p.o) at a dose of $100 \mathrm{mg} / \mathrm{kg}$ and $200 \mathrm{mg} / \mathrm{kg}$ respectively. The feeding regimens lasted for 14 days. Results show that the extract contains polyphenols, glycosides, reducing sugars and alkaloids. The mean RBC count for control was $4.44 \pm 0.15 \times 10^{6}$ cells $/ \mathrm{mm}^{3}$, this did not differ significantly from the test groups. The total WBC counts were $3.79 \pm 0.15 \times 10^{3}$ cells $/ \mathrm{mm}^{3}, 3.37 \pm 0.19 \times 10^{3}$ cells $/ \mathrm{mm}^{3}$ and $5.54 \pm 0.39 \times 10^{3}$ cells $/ \mathrm{mm}^{3}$ for groups 1,2 , and 3 respectively. WBC was significantly $(\mathrm{P}<0.01)$ higher in the high dose (group 3$)$ compared with control. Mean PCV (\%) were $33.60 \pm 0.81,37.20 \pm 0.80$ and $34.80 \pm 1.35$ for groups 1,2 , and 3 respectively. The PCV was significantly $(\mathrm{P}<0.05)$ higher in low dose extract recipients (group 2) than in control. Hb content, MCV and $\mathrm{MCH}$ did not differ significantly among the groups, but $\mathrm{MCHC}$ was significantly lower in the test groups compared with control group. Neutrophils were significantly $(\mathrm{P}<0.001)$ reduced in the test groups, while the eosinophils and monocytes count were significantly increased in the test groups than in controls. In conclusion, the extract has little or no effect on RBC count, PCV, MCV and MCH. But low doses of the extract significantly increased the $\mathrm{Hb}$ count while high doses significantly increased WBC count, probably due to increase in eosinophil and monocyte counts. MCHC was dose-dependently reduced. The extract was also observed to contain polyphenols, alkaloids, glycosides and reducing sugars.
\end{abstract}

Key words: Gonglonema latifolium, root extract, Phytochemistry, blood.

\section{Introduction}

Gonglonema latifolium is a climbing perennial plant that belongs to the family of asclepidaceae (Okafor and Ejiofor, 1996; Eleyinmi et al, 2006). It is a rainforest plant which has been traditionally used in the south-eastern part of Nigeria for the management of diseases such as diabetes, high blood pressure etc. (Ugochukwu et al, 2003). Gonglonema latifolium is also used in the western African sub-region for a number of medicinal and nutritional purposes such as spice and vegetable (Dalziel, 1937). It is commonly called 'Utazi' and 'Arokeke' in the south-eastern part of Nigeria. The plant is traditionally used in the control of weight gain in lactating women and promotes fertility in women (Schneider et al, 2003). It is also used to treat malaria, stomach ache, worm infestations, cough, ulcers, and cancers. The hypoglycaemic and antihyperglycaemic properties of the ethanolic stem extract of Gonglonema latifolium have been reported by Farombi (2003).

Gonglonema latifolium leaves extract is rich in proteins $(27.2 \% \mathrm{DM})$ which compared well with values reported for chickpea $(24.0 \% \mathrm{DM})$ and other protein rich plants. Phytochemical analysis of leaves extract of Gonglonema latifolium reveals the presence of essential oil, saponins (asterglycosides), alkaloids, minerals like calcium, phosphorus, magnesium, copper and potassium (Schneider et al, 2003; Eleyinmi and Bressler, 2007).

Blood is a tissue which consists of fluid plasma in which are suspended a number of formed elements (erythrocyte, leucocyte and thrombocytes). Its primary function is to provide a link between the various organs and cells of the body, and to maintain a constant cellular environment by circulating through every tissue delivering nutrient to them and removing waste products (Bowman and Rand, 1980). The blood cells (erythrocytes, leucocytes and thrombocytes) exist at fairly constant levels, suggesting the existence of feedback mechanism for the cells (Guyton and Hall, 2006). The effects of ethanolic stem extract of Gonglonema latifolium have been widely reported but there is paucity in scientific 
A. B. Antai et al

literature on the effect of the root extract, especially on hematological parameters. It is therefore the aim of this study to investigate the effect of ethanolic root extract of Gonglonema latifolium on some blood parameters and its biochemical constituents.

\section{Materials and Methods}

Experimental animals

Albino Wistar rats (weighing between 180$210 \mathrm{~g}$ ) were used for this study. They were obtained from the animal house of the Department of Physiology, University of Calabar-Nigeria and housed at room temperature $\left(28 \pm 2^{\circ} \mathrm{C}\right)$.

\section{Experimental plant}

Fresh mature roots of Gonglonema latifolium were obtained from the botanical garden of University of Calabar-Nigeria and were identified by the Chief Herbarium Officer of Botany Department, University of Calabar-Nigeria.

\section{Preparation of plant extract}

The roots were washed to free debris, sun dried. They were later oven (Astell Hearson, England) dried at $35^{\circ} \mathrm{C}-40^{\circ} \mathrm{C}$. The dried roots were ground to fine powder and $500 \mathrm{~g}$ powder was percolated in $300 \mathrm{mls}$ of ethanol $(80 \% \mathrm{v} / \mathrm{v}, \mathrm{BDH})$ for 24 hours. It was thereafter filtered with Whatman No. 1 filter paper. The filtrate was then dried to paste at $45^{\circ} \mathrm{C}$. This resulted in $56 \mathrm{~g}$ (yielding $11.20 \%$ ) of the crude ethanolic extract. A stock solution of $1 \mathrm{~g} / \mathrm{ml}$ was prepared for the experiments.

\section{Experimental protocol}

Eighteen (18) albino Wistar rats were randomly assigned into 3 groups of 6 rats each. Group 1 was the control group while groups 2 and 3 were the test groups. They were all fed on normal rat chow and drinking water. Groups 2 and 3 in addition received $100 \mathrm{mg} / \mathrm{kg}$ (Low dose) and $200 \mathrm{mg} / \mathrm{kg}$ (high dose) of ethanolic extract of Gonglonema latifolium extract (orally, once daily) respectively. The feeding regimens lasted for 14 days.

\section{Collection of blood samples}

Rats were sacrificed using chloroform anaesthesia. Blood samples were collected by cardiac puncture into EDTA capped bottles with the aid of a $5 \mathrm{ml}$ syringe. The blood samples were then used for the experiments.

\section{Phytochemical screening of Gonglonema latifolium}

The different phytochemical tests were carried out using standard laboratory techniques. Alkaloids, glycosides (Salkowski test) and saponins (Frothing test) were identified following the method of Sofowora, (1984). The presence phlobatanins, anthraquinones, flavonoids and tannins were tested using the method of Trease and
Evans, (1989). Identification of polyphenols and reducing compounds was by the method of Gullei, (1982).

\section{Determination of hematological parameter}

Red blood cell (RBC) count was done using the conventional method of Dacie and Lewis (2001). Blood was diluted to 1:200 with Hayem's fluid which preserved the corpuscles and then counted with a Neubauer counting chamber under a light microscope. The counting of total white blood cells was done after the method of Brown (1974) using a diluting fluid (Turk's fluid) in a ratio of 1:20. Differential white blood cell count was carried out using Leishman's stain. The conventional method (using Sahli's haemoglobinometer) was employed for estimation of hemoglobin $(\mathrm{Hb})$ content of the blood while packed cell volume (PCV) was done using the macrohaematocrit method (Dacie and Lewis, 2001).

\section{Calculation of absolute values}

The different absolute values: mean corpuscular volume (MCV), mean corpuscular hemoglobin $(\mathrm{MCH})$ and mean corpuscular hemoglobin concentration (MCHC) were calculated from values of $\mathrm{RBC}, \mathrm{PCV}$ and $\mathrm{Hb}$ as follows:

$\mathrm{MCV}($ millimicron $)=\mathrm{PCV} \% \quad \mathrm{x} 10 / \mathrm{RBC}$ count $\left(\mathrm{x}\right.$ million per $\left.\mathrm{mm}^{3}\right)$; $\mathrm{MCH}($ picogram $)=\mathrm{Hb}$ $\mathrm{g} / \mathrm{dl} \times 10 / \mathrm{RBC}$ count (x million per $\mathrm{mm}^{3}$ ) and $\mathrm{MCHC}($ picogram $)=\quad \mathrm{Hb} \mathrm{g} / \mathrm{dl} \times 100 / \mathrm{PCV} \%$

\section{Statistical analysis}

All data are presented as mean \pm SEM. The one way ANOVA was used to analyze the data, followed by a post-hoc test (LSD). The results were considered significant at $\mathrm{p}$ values of less than 0.05 .

\section{RESULTS}

Phytochemical screening of Gonglonema latifolium extract

The result of phytochemical screening of ethanolic root extract of Gonglonema latifolium is shown in Table 1 . The results show that the root extract of Gonglonema latifolium contains polyphenols in abundance. Alkaloids, glycosides and reducing sugars were present in moderate amounts while saponins, tannins, flavonoids, phlobatanins, anthraquinones and hydroxymethyl anthraquinones were absent.

\section{Hematological parameter in control and test groups}

As summarized in table 2, the mean RBC counts were $4.44 \pm 0.15,4.90 \pm 0.26$ and $4.63 \pm$ $0.12 \times 10^{3}$ cells $/ \mathrm{mm}^{6}$ for the control, low and high dose extract fed groups respectively. Although, increases in RBC counts were observed in the low 
Gongronema latifolium, and some haematological indices

and high dose group, these were not statistically different from the control groups.

The mean total WBC count in control group was $3.79 \pm 0.15 \times 10^{3}$ cells $/ \mathrm{mm}^{3}$. It was significantly $(\mathrm{P}<0.01)$ higher in the high dose recipients $\left(5.54 \pm 0.39 \times 10^{3}\right.$ cells $\left./ \mathrm{mm}^{3}\right)$ compared with control and low dose recipients which had a total WBC of $3.37 \pm 0.19 \times 10^{3}$ cells $/ \mathrm{mm}^{3}$.

The mean PCV was significantly higher in the low dose recipients $(37.20 \pm 0.80 \%)$ than in control $(33.60 \pm 0.81 \%)$. The mean PCV of the high dose group $(34.80 \pm 1.35 \%)$ was not significantly different to that of the controls, (table 2).

Table 1: Phytochemical screening of Gonglonema latifolium extract

\begin{tabular}{ccc}
\hline SN & $\begin{array}{c}\text { Chemical } \\
\text { constituents }\end{array}$ & $\begin{array}{c}\text { Score } \\
\text { indication }\end{array}$ \\
\hline 1 & Alkaloids & + \\
2 & Glycosides & + \\
3 & Saponins & - \\
4 & Tannins & - \\
5 & Flavonoids & - \\
6 & Reducing sugars & + \\
7 & Polyphenols & ++ \\
8 & Phlobatanins & - \\
9 & Anthraquinones & - \\
10 & Hydroxymethyl- & - \\
& anthraquinones & \\
\hline
\end{tabular}

Table 2: Hematological parameters in the different experimental groups of rats.

\begin{tabular}{|c|c|c|c|}
\hline Parameters & $\begin{array}{l}\text { Group } 1 \\
\text { (Control) }\end{array}$ & $\begin{array}{c}\text { Group } 2 \\
(\text { Low } \\
\text { dose })\end{array}$ & $\begin{array}{c}\text { Group } 3 \\
\text { (High } \\
\text { dose) } \\
\end{array}$ \\
\hline $\begin{array}{c}\mathrm{RBC} \\
\left(\mathrm{x} 10^{6} / \mathrm{mm}^{3}\right)\end{array}$ & $4.44 \pm 0.15$ & $\begin{array}{c}4.90 \pm \\
0.26\end{array}$ & $\begin{array}{c}4.63 \pm \\
0.12\end{array}$ \\
\hline $\begin{array}{c}\text { WBC } \\
\left(\times 10^{3} / \mathrm{mm}^{3}\right)\end{array}$ & $3.79 \pm 0.15$ & $\begin{array}{c}3.37 \pm \\
0.19\end{array}$ & $\begin{array}{c}5.54 \pm \\
0.39 * *, \mathrm{~b}\end{array}$ \\
\hline $\begin{array}{l}\mathrm{PCV} \\
(\%)\end{array}$ & $\begin{array}{l}33.60 \pm \\
0.81\end{array}$ & $\begin{array}{c}37.20 \pm \\
0.80^{*}\end{array}$ & $\begin{array}{c}34.80 \pm \\
1.35\end{array}$ \\
\hline $\begin{array}{l}\mathrm{Hb} \\
(\mathrm{g} / \mathrm{dl})\end{array}$ & $\begin{array}{c}14.06 \pm \\
1.30\end{array}$ & $\begin{array}{c}14.45 \pm \\
0.16\end{array}$ & $\begin{array}{c}13.38 \pm \\
0.43^{*}\end{array}$ \\
\hline $\begin{array}{l}\text { MCV } \\
\text { (fl) }\end{array}$ & $\begin{array}{c}76.04 \pm \\
3.58\end{array}$ & $\begin{array}{c}76.56 \pm \\
3.39\end{array}$ & $\begin{array}{c}75.65 \pm \\
4.58\end{array}$ \\
\hline $\begin{array}{l}\mathrm{MCH} \\
(\mathrm{pg})\end{array}$ & $\begin{array}{c}31.80 \pm \\
1.28\end{array}$ & $\begin{array}{c}29.81 \pm \\
1.58\end{array}$ & $\begin{array}{c}29.09 \pm \\
1.63\end{array}$ \\
\hline $\begin{array}{c}\mathrm{MCHC} \\
(\%)\end{array}$ & $\begin{array}{c}41.90 \pm \\
0.71\end{array}$ & $\begin{array}{c}38.88 \pm \\
0.57 *\end{array}$ & $\begin{array}{l}38.51 \pm \\
0.53 * *\end{array}$ \\
\hline
\end{tabular}

$* \mathrm{P}<0.05, * * \mathrm{P}<0.01$ vs control. $\mathrm{b}=\mathrm{P}<0.01$ vs low dose. Values are mean \pm SEM, $n=6$.
Table 3: Differential white blood cell count in the different experimental groups of rats.

\begin{tabular}{|c|c|c|c|}
\hline Parameters & $\begin{array}{l}\text { Group } 1 \\
\text { (Control) }\end{array}$ & $\begin{array}{c}\text { Group } 2 \\
(\text { Low } \\
\text { dose })\end{array}$ & $\begin{array}{c}\text { Group } 3 \\
\text { (High } \\
\text { dose) }\end{array}$ \\
\hline $\begin{array}{l}\text { Neutrophils } \\
(\%)\end{array}$ & $\begin{array}{l}23.20 \pm \\
1.28\end{array}$ & $\begin{array}{l}13.60 \pm \\
0.40^{* * * *}\end{array}$ & $\begin{array}{l}15.60 \pm \\
0.51 * * * \\
\quad \text { a }\end{array}$ \\
\hline $\begin{array}{c}\text { Lymphocytes } \\
(\%)\end{array}$ & $\begin{array}{c}64.00 \pm \\
0.71\end{array}$ & $\begin{array}{l}68.40 \pm \\
0.40^{* * *}\end{array}$ & $\begin{array}{c}62.20 \pm \\
1.02^{\mathrm{c}}\end{array}$ \\
\hline $\begin{array}{c}\text { Basophils } \\
(\%)\end{array}$ & $\begin{array}{l}0.60 \pm \\
0.30\end{array}$ & $\begin{array}{c}0.40 \pm \\
0.30\end{array}$ & $\begin{array}{c}0.40 \pm \\
0.30\end{array}$ \\
\hline $\begin{array}{l}\text { Monocytes } \\
\quad(\%)\end{array}$ & $\begin{array}{c}8.40 \pm \\
0.93\end{array}$ & $\begin{array}{c}7.80 \pm \\
0.70\end{array}$ & $\begin{array}{l}14.20 \pm \\
0.70^{* * *}\end{array}$ \\
\hline $\begin{array}{l}\text { Eosinophils } \\
\qquad(\%)\end{array}$ & $\begin{array}{c}4.80 \pm \\
0.37\end{array}$ & $\begin{array}{c}9.80 \pm \\
0.58 * * *\end{array}$ & $\begin{array}{c}7.60 \pm \\
0.60 * * * \\
\text { a }\end{array}$ \\
\hline \multicolumn{4}{|c|}{$\begin{array}{l}* * * \mathrm{P}<0.01 \text { vs control. } \mathrm{a}=\mathrm{P}<0.05, \mathrm{c}=\mathrm{P}<0.001 \text { vs } \\
\text { low dose. Values are mean } \pm \mathrm{SEM}, \mathrm{n}=6 .\end{array}$} \\
\hline \multicolumn{4}{|c|}{$\begin{array}{l}\text { The mean control Hb concentration was } 14.06 \\
\pm 1.30 \mathrm{~g} / \mathrm{dl} \text {. The Hb concentration of the high dose } \\
\text { group was significantly }(\mathrm{P}<0.05) \text { lower compared } \\
\text { with controls. The increase in Hb observed in low } \\
\text { dose group was not significantly different from } \\
\text { controls. }\end{array}$} \\
\hline
\end{tabular}

Also, shown in table 2, are the mean values of MCV for the control, low and high dose groups which were $76.04 \pm 3.58,76.56 \pm 3.39$ and $75.65 \pm$ $4.58 \mathrm{fl}$ respectively. These values were not significantly different from each other. The mean values of $\mathrm{MCH}$ were also not significantly different among the groups. But the MCHC was significantly higher in the low $(38.88 \pm 0.57 \%$, $\mathrm{P}<0.05)$ and high $(38.51 \pm 0.53, \mathrm{P}<0.01)$ dose groups compared with controls.

\section{Differential white blood cell counts in control and tests groups}

The mean values of neutrophils in low and high dose groups $(13.60 \pm 0.40 \%$ and $15.60 \pm$ $0.51 \%$ respectively) were significantly $(\mathrm{P}<0.001)$ low compared with controls $(23.20 \pm 1.28 \%)$. The high dose group in turn had a significantly $(\mathrm{P}<0.05)$ higher neutrophils count than the low dose group, (table 3).

The mean value of lymphocytes in the low dose group $(68.40 \pm 0.40 \%)$ was significantly $(\mathrm{P}<0.001)$ higher compared with values obtained for control $(64.00 \pm 0.71 \%)$ and high dose $(62.20 \pm$ $1.02 \%$ ) groups, (table 3 ).

Eosinophils were not significantly different among the groups. Monocyte counts was significantly $(\mathrm{P}<0.001)$ higher in the high dose 
extract recipient group than in control and low dose groups. The test groups had significantly $(\mathrm{P}<0.001)$ higher basophils than controls; the high dose group in turn had a significantly $(\mathrm{P}<0.05)$ lower counts than the low dose group, (table 3 ).

\section{Discussion}

The phytochemical constituents and effect of ethanolic root extract of Gonglonema latifolium on some hematological parameter in rats were studied. The results obtained showed that the extract contains an agent with profound effects on blood parameters. The results show that the root extract of Gonglonema latifolium contains polyphenols in abundance with moderate amounts of alkaloids, glycosides and reducing sugars while saponins, tannins, flavonoids, phlobatanins, anthraquinones and hydroxymethyl anthraquinones were absent compared with the leaves extract which was reported by Schenider et al (2003) to contain essential oil, saponins (asterglycosides) and alkaloids.

From the results obtained, the control values of red blood cells obtained agreed with what was reported elsewhere (Eastham et al, 1993; 1983). However, red blood cells were not significantly affected by Gonglonema latifolium root extract in the doses given in this study.

The picture for PCV was not clear as there was no difference between the high dose and control groups but significant increase occurred between the control and the low dose group. The reason for this is not quite clear.

Hemoglobin concentration in this study agreed with report of Dacie and Lewis, 2001 conducted in rats. Paradoxically, there was a slight but significant decrease between rats that received high and low doses of Gonglonema latifolium root extract, even though the former did not differ from controls.

White blood cell count in the three groups studied fell within the reference range as reported for rats (Constable, 1963). The extract appeared to increase WBC count in a dose dependent manner, although, the increase in the low dose compared to controls was not significant. The effect of the extract on the total WBC count could be due to the presence of glycosides. This compound has an antiinflammatory property and so has vital effect on inflammatory processes of some pathological states such as bacterial infection, malaria and liver diseases (Ugochukwu, 2002).

The differential WBC count shows variations in the different parameters. The results obtained for neutrophils in the extract treated group agreed with the report that leucopenia occurs in some pathological states (Baker and Silverton, 1998). The lymphocytes in the three experimental groups studied fell within the reference range in rats (Constable, 1963). There was significant increase in the low dose treated group compared to the control and high dose groups. This is not dose dependent. Results obtained in this study for monocytes and eosinophils agree with values stated by Guyton and Hall (2006). They were significantly higher in the test groups compared to control. MCV and MCH did not differ significantly among the groups. MCHC in the test groups decreased significantly than in controls.

In conclusion, Gonglonema latifolium ethanolic root extract has little or no effect on the RBC count and haemoglobin content of blood but causes an increase in total WBC count probably by increasing monocytes and eosinophils in the blood. The extract was also observed to contain abundant polyphenols and moderate amounts of alkaloids, glycosides and reducing sugars which would have contributed to the observed effect of the extract on the blood parameters.

\section{References}

Asperhein, M. K. (2002). Pharmacology: An Introductory Text. W. B. Saunders Publisher, Philadelphia. Pp 135- 191.

Baker, F. J and Silverton, R. E. (1998). Introduction to Medical laboratory Technology. $7^{\text {th }}$ ed. Reed Education and Professional Publishers. Pp 339-354.

Bowman, W. C and Rand, M. T. (1980). Drugs affecting coagulation, fibrinolysis, haematopoiesis and the functioning of blood cells. In: Textbook of Pharmacology. Blackwell Publishers, Oxford. Pp 1-21, 53.

Constable, B. J. (1963). Changes in blood volume and picture during the life of the rat and guinea pig from birth to maturity. $J$ Physiol, London. 129: 229-238.

Dacie, J. V and Lewis, S. M. (2001). Practical Haematology. $11^{\text {th }}$ ed, Longman Group.Ltd. Hong Kong. pp 11-17.

Dalziel, J. M. (1939). The useful plants of west tropical Africa. Crown Agents for the Colonies Publisher, London. P. 230.

Easthan, R. D and Jance, J. (1983). The normal ranges of haematological indices in man. $B r . J$. Physiol. 143:203 -209.

Easthan, R. D and Slade, R. R. (1993). Clinical Haematology. $7^{\text {th }}$ ed. Tokyo, Butter WorkHeinemann Ltd. Pp 5-9, 83-105.

Eleyinmi, A. F., Bressier, D. C., Amo, I. A., Sporns, P. Oshodi, A. A. (2006). Chemical composition of bitter cola (Garcina kola) seed and hull. Polish J Food Nutr Sci. 12(1): 120128.

Eleyinmi, A. F. 2007. Chemical composition and antibacterial activity of Gonglonema latifolium. J Zhejiang Univer Sci. 8(5): 302-308.

Eleyinmi, A. F and Bressler, D. C. (2007). Chemical composition and anti-bacterial 
Gongronema latifolium, and some haematological indices

activity of Gonglonema latifolium. J Zhejiang Univer Sci. 8(5): 302-308.

Farombi, E. O. (2003). African indigenous plants with chemotherapeutic potentials and biotechnological approach to the production of bioactive prophylactic agent. Afri J. Biotechnol. 2(12); 662-671.

Guyton, A. C and Hall, J. E. (2006). Textbook of Medical Physiology. $11^{\text {th }}$ ed. W. B. Saunders Company, Philadelphia. Pp 700-825.

Nelson, M. T., Muray, E., Chenge, H., Rubart, M., Santan, L. F., Boney, K. H and Ledere, M. T. 1989. Relaxation of arterial smooth muscle by calcium sparks. Sciences. 270: 633-639.

Nelson, M. T., and Quayle, J. M. (1990). Physiological roles and properties of potassium channels in vascular smooth muscle cells. Am J Physiol. 268:C799-C822.
Okafor, J. C., and Ejiofor, M. A. U. (1996). Strategies for enhancement of utilization of potential edible woody forest species of southeastern Nigeria. The biodiversity of African plant. Kluwe. The Netherlands, pp 684-695.

Schneieder, C. R., Sheidt, K., Brietmaier, E. (2003). Four new pregnant glycosides from Gonglonema latifolium. (Asclepidaceous). J Parkische Chem Chenisker-Zutung. 353: 532536.

Ugochukwu, N. H., Babady, U. E., Cobourre, M. K and Gosset, S. R. (2003). The effect of Gonglonema latifolium extract on serum lipid profile and diabetes rabbit stress in hepatocytes of diabetes rats. J Biosci. 28(1): 1-5.

Weishrodt, N. W. (1991). Motility of the small intestine. In: Gastrointestinal Physiology. Johnson, L. R (Ed.) $4^{\text {th }}$ edition. Mosby Year Book. 